\title{
Pepsinogen C Measurement
}

National Cancer Institute

\section{Source}

National Cancer Institute. Pepsinogen C Measurement. NCI Thesaurus. Code C100470.

The determination of the amount of pepsinogen C present in a sample. 